\title{
Housing for Sustainable Societies. Children's Perception and Satisfaction with Their House in Countries around the World
}

\author{
Claudia Bacter *(D), Sorana Săveanu (D), Raluca Buhaș (D) and Cristiana Marc (D) \\ Faculty of Social Sciences, University of Oradea, 410087 Oradea, Romania; soranasav@gmail.com (S.S.); \\ ralubuhas@gmail.com (R.B.); marc.cristiana@gmail.com (C.M.) \\ * Correspondence: claudianbacter@gmail.com
}

check for updates

Citation: Bacter, C.; Săveanu, S. Buhas, R.; Marc, C. Housing for Sustainable Societies. Children's Perception and Satisfaction with Their House in Countries around the World. Sustainability 2021, 13, 8779. https://doi.org/10.3390/su13168779

\section{Academic Editors:}

Filomena Maggino, Leonardo

Salvatore Alaimo, Enrico Di Bella,

Marco Fattore and Matteo Corsi

Received: 30 June 2021

Accepted: 3 August 2021

Published: 6 August 2021

Publisher's Note: MDPI stays neutral with regard to jurisdictional claims in published maps and institutional affiliations.

Copyright: (C) 2021 by the authors. Licensee MDPI, Basel, Switzerland. This article is an open access article distributed under the terms and conditions of the Creative Commons Attribution (CC BY) license (https:// creativecommons.org/licenses/by/ $4.0 /)$.

\begin{abstract}
Background: Adequate housing conditions and access to basic house amenities are fundamental human rights and indicators of individual wellbeing. The paper aims to present children's perception regarding housing conditions and household goods and their impact on children's overall satisfaction with their house. (2) Methods: We aim to determine the contribution of housing conditions and household goods on children's satisfaction with their home in 31 countries worldwide. To capture differences in children's satisfaction with their house based on their housing conditions, we analyzed models conducted on data from 10 lower- and upper-middle-income and 20 highincome countries. We used secondary analysis on data from the third wave of Children's Worlds: International Survey of Children's Well-Being (ISCWeb) (87,000 children, aged 10-12, worldwide). (3) Results: The results show that there is a link between the material conditions of the family and children's satisfaction with the house they live in, and also that having a place to study and access to internet are the main factors related to housing that explain children's satisfaction. (4) Conclusions: Children mostly appreciate the way housing setting and household goods contribute and ensure their proper development through the creation of a stimulating home learning environment. Results are helpful in setting future standards to increase children's wellbeing and quality of life, and ensure adequate housing as one of the pillars of sustainable development.
\end{abstract}

Keywords: children; housing conditions; household goods; satisfaction with the house; sustainable development

\section{Literature Review \\ 1.1. Introduction}

The progress of any society is based on investment in children to ensure the necessary context for an adequate physical and psychological development by satisfying their needs for food, shelter, safety, health, a safe space to study, play, etc. All these aspects are interrelated. Societies overall will benefit if decent living conditions are ensured for all children [1].

Our paper presents children's perspective on their housing conditions and household goods and investigates children's satisfaction with their house. In the first part of the present paper, we depict the theoretical background for our topic. We discuss the concept of housing in the context of sustainable development. Further, we present and discuss the results of our study regarding children's satisfaction with their house in countries all over the world. In the final section, we outline some concluding remarks based on our main research results.

\subsection{Housing in the Context of Sustainable Development to Ensure People Wellbeing}

The 2030 Agenda for Sustainable Development aims to globally address social, educational, health, and environmental issues to reduce poverty and social inequalities. These goals can be achieved only through a common contribution of all countries worldwide 
to create a sustainable society [2]. The 2030 Agenda encompasses 17 global objectives grouped on the three pillars of sustainable development: economic, social, and environmental pillars [3]. By approaching housing conditions, we tackled five of the 2030 Agenda sustainable development goals (SDGs), namely: SDG3-Ensuring healthy lives and promoting well-being at all ages; SDG10-Reducing inequalities and ensuring no one is left behind; SDG11-Making cities inclusive, safe, resilient and sustainable; SDG6-Ensuring access to water and sanitation for all; and SDG7-Ensuring access to energy for all.

Globally, the efforts of the World Health Organization and Member States aim to overcome the boundaries of health sector and address multi-sectoral issues, as housing is one of the concerns. Access to running water and improving housing conditions, especially for vulnerable social groups, are key elements to reduce health risks [4]. Lack of access to good quality of running water, as well as lack of sanitation, are harmful in all aspects of quality of life for poor families [5].

By aiming at the achievement of the sustainable development goals, the society, as a whole, will contribute to a better quality of life [6]. In this context, we need to take into consideration the concept of livability that approaches in a more complex manner aspects related to living conditions and quality of life. "Livability refers to the quality of life, standard of living, or general well-being of a population", and binds subjective wellbeing to the fulfilment of needs $[7,8]$ (p. 197). One of the hypotheses of livability theory suggests that meeting the needs depends both on external living conditions and the way people relate to them, due to the fact that there is a subjective assessment of individuals regarding their living environment $[9,10]$, and of the way this assessment affects their "physical, social, and mental well-being" [1] (p. 7). Therefore, in sustainable societies individuals relate to their life in a positive manner.

Another hypothesis of livability theory brings into question the responsibility of societies to meet human needs and points out the differences between societies if these requirements are not fulfilled [9]. Livability can be measured by taking into consideration the standard or level of living [11]. Good living conditions refer to the livability of the environment [12].

Living conditions are indicators of sustainable development and are measured based on: "access to improved water; access to improved sanitation facilities; sufficient, not overcrowded, living area; structural quality/durability of dwellings; security of tenure". Inadequate living conditions are associated with social groups at risk, poverty, and have implications for the progress of societies [13] (p. 50).

People all over the world are entitled to a decent life supported by access to basic goods [14] and decent living standards [15]. By looking at basic human needs, Rao and Min [15] proposed the Decent Living Standards (DLS), a set of minimum required material conditions for both physical and social wellbeing, to support a decent life. Among other aspects, poverty implies crowded living spaces, poor housing, and lack of basic household amenities, and affects the fulfilment of human rights [13].

Living conditions is one of the dimensions of physical wellbeing and refers also to household requirements, such as indoor toilet or an accessible water supply. The Living Condition Index (LCI), a standardized aggregate score, is a good example of how living conditions indicators look like. LCI encompasses indicators classified in seven categories, among which housing tackles various aspects of living conditions [16]. Likewise, Economic Living Standards Index (ELSI) developed in New Zeeland, is another measure for living standards [17].

The Convention on the Rights of the Child stresses out the equal role of children's social, economic, civic, political, and cultural rights and emphasizes their interconnection. Adequate standard of living is essential for child's progress in every aspect [18]. Therefore, children's living settings, as well as their wellbeing, need to be assessed from multiple dimensions and perspectives in a holistic view. UNICEF [19], the European Commission [20], and the OECD [21] have developed and used a set of child wellbeing indicators among which is housing conditions. 


\subsection{Housing-Conceptual Clarifications}

Both concepts of quality of life and sustainable development relate to housing [22]. There is a massive body of research on the relationship between housing and its impact on adults' quality of life and wellbeing [23,24]. Even if housing conditions is demonstrated to have a significant impact also on children's wellbeing [25], this aspect is insufficiently investigated so far [23]. Moreover, there are few studies that use child self-reported data on home environment. Research results show that a high level of children's satisfaction with their life relate to material wellbeing [26]. Unlike adults, the sources of happiness for young children, until adolescence begins, seem to be material goods [27].

The physical characteristics of the household may constitute an essential explanatory factor of the differences in children's wellbeing across socioeconomic contexts [28]. The role of housing on children's lives still needs to be explored

Housing is a multidimensional topic and provides information about living conditions. The literature review points out that housing is approached as material good, and also as a result of the actions of people to provide housing [29]. Physical settings of the household, and basic amenities in the dwelling are some of the dimensions that need to be investigated to indicate housing conditions. Difficulties in measuring the impact of housing conditions on wellbeing are due to few available comparable indicators. Studies state that housing conditions should be measured by using both physical characteristics of the household, such as access to electricity, water, indoor flushing toilets, etc., and environmental factors of the regions, such as pollution, noise, etc. [30]. Housing deprivation defines a household facing problems such as crowding, no bathroom or indoor flushing toilet, leaking roof, darkness, etc. There is scientific proof that the quality of housing has major impact on the physical and emotional health of people, Moreover, low quality housing conditions in childhood have further implications on adulthood [31] and are associated with an increased risk of mortality in adulthood [32].

Differences of housing quality are registered between regions and countries. An analysis of housing indicators can shed light on the economic conditions linked to health outcomes, so that in regions with higher income it is more likely to find adequate housing [16]. In some lowincome European countries, such as Romania, Bulgaria, and Latvia, a quite high percentage of the population confronts problems related to housing, while in higher-income states, such as Iceland, Norway, Switzerland, and Finland, very few face housing deprivation [33]. Moreover, a higher socio-economic status is associated with a better quality of housing [32]. However, differences between countries regarding the impact of housing quality on subjective wellbeing are found due to various housing systems [34].

\subsection{Quality of Housing: Children's Perspective and Satisfaction}

A healthy development of children depends on various factors, among which is the environment they live in. Housing settings are essential in this regard because they affect children wellbeing and health and they are related to sustainability [31,35]. Children's educational outcomes and health, as well as their transition to adulthood are impacted by housing quality [36]. In a study conducted on 656 respondents aged between 14 and 16 children indicated the negative effects of bad housing on their health, educational attainment, and social lives, such as depression, irritability, illnesses, and stress [37]. In the same vein, in another study of the United Kingdom's Office for National Statistics, 48 children aged between 10 and 15 indicate good housing, such as own space and privacy as well as basic amenities as necessary conditions for their wellbeing [38].

Barnes, Butt, and Tomaszewski [39] state that housing quality determines children's outcomes which can help understand their consequences on children's wellbeing. The impact of overcrowding on children relates to their health as well as their educational outcomes and attainment. One's own bedroom, a quiet place to study and do homework positively affect children's school performance and cognitive development [23,25,40-42]. Lack of some household goods, a lower socio-economic status, and, therefore, poor housing conditions are also correlated with lower levels of engagement in prosocial behaviors [43]. 
Low housing quality generates emotional, mental, and physical health problems for children [39,44,45], and also determines their social and economic opportunities later in life [46]. Therefore, an adequate housing setting provide the necessary context for a proper development during childhood [30].

There are several approaches to assess house-related aspects. There is no doubt that household conditions and goods reflect the socioeconomic status of the family and are strongly influenced by the specificities of each region. In this regard, different indexes used in investigating the level of poverty, deprivation, or risk situations include such living conditions indicators. On the other hand, regarding children's outcomes and development, alongside with these indicators that reflect the socioeconomic status of the family, the home environment where children develop is just as important. In this sense, several studies bring into the forefront the importance of the home learning environment in supporting and stimulating children's development [47-49]. In this case, not the material resources available in the house, but a stimulating home environment is the one that contributes to children's development and positive educational outcomes. Studies that focus on these aspects use various indicators, concepts, and measurement scales, such as: home literacy environment [47], home learning environment (HLE) [50-52], and the Home Observation for Measurement of the Environment (HOME) [53-55]. The items used in these scales and inventories refer to the quality and quantity of stimulation and support available to a child in the home environment. When looking at satisfaction with the quality of the house, we have to consider indicators of physical housing setting and household goods, as well as indicators of the social and study environment.

\section{Research Methodology}

\subsection{Aim and Research Objectives}

We aim to analyze children's perception about the house they live in. In our research we investigate the impact of housing conditions and household goods on children's overall satisfaction with their house.

Most research focus on factual data collected within household inquiries based on data provided by adults in the household. However, children may relate differently to their housing condition and therefore we are interested in the items that contribute significantly to their home satisfaction. Taking into account that a house and a home are closely connected, we analyze the household conditions that meet the basic needs, as well as the possession of those goods that contribute to a better life and a good chance for a proper development of a child.

The research objectives are the following:

- RO1. Descriptive analysis of children's perspective on housing conditions and household goods in 31 countries.

- RO2. Analysis of the impact of housing conditions and household goods on children's overall satisfaction with their house.

- RO3. Analysis of the impact of basic household amenities on children's overall satisfaction with their house in 10 lower-middle and upper-middle income economies.

- $\quad \mathrm{RO} 4$. Investigate the factors that explain children's satisfaction with their house in 20 high-income economies.

The study is based on the following research questions: What is the level of children's satisfaction with their house in countries around the world? Are there any differences by country category in terms of house satisfaction, respectively regarding housing conditions and household goods? Lastly, what are the main factors that explain the level of children's satisfaction with their house?

\subsection{Analysis Plan: Method, Materials, Sample, and Variables}

In our study we used data collected within the third wave of Children's Worlds. The International Survey of Children's Well-Being (ISCWeB), where over 128,000 children aged 
8-12 were interviewed in countries all over the world. The third wave, the largest one of the study, was undertaken between 2016 and 2019.

Our research is based on a quantitative approach, using secondary data analysis. The main advantage of this method is the opportunity of using and promoting data collected within surveys based on large samples. This method also has some disadvantages, and one of them refers to the fact that data is already collected using a research tool that was designed based on the objectives followed within the initial research project. Thus, in the secondary data analysis, it is possible to encounter some difficulties regarding the achievement of new research objectives that were subsequently established [56]. In the secondary data analysis, we have less control over the type of variables included in the analysis; however, we have access to great amount of representative and reliable data.

Our research is based on 87,384 cases selected from the Children's Worlds project. The sample includes children in the 10 and 12 age group, from 31 countries. Children found in the group of age 8 were excluded from our analysis because questions regarding housing conditions were not addressed to them in the questionnaires.

The 31 countries included in the study are the following: Albania, Belgium, Brazil, Switzerland, Chile, Germany, Algeria, England, Spain, Finland, France, Greece, Hong Kong, Croatia, Hungary, Indonesia, Israel, India, Italy, South Korea, Sri Lanka, Malta, Namibia, Norway, Nepal, Poland, Russia, Taiwan, Vietnam, Wales, and South Africa. We included countries in the categories established by the World Bank, based on income groups (see Table 1) and geographic regions (see Table 2) [57].

Table 1. Country category by income.

\begin{tabular}{cc}
\hline & Percent \\
\hline high-income economies & 52.5 \\
upper-middle-income economies & 35.4 \\
lower-middle income economies & 12.1 \\
\hline
\end{tabular}

Table 2. Country category by region.

\begin{tabular}{cc}
\hline & Percent \\
\hline Europe and Central Asia & 37.9 \\
East Asia and Pacific & 32.4 \\
Latin America and the Caribbean & 4.2 \\
Middle East and North Africa & 7.6 \\
South Asia & 7.3 \\
\hline
\end{tabular}

The project Children's Worlds: The International Survey of Children's Well-Being was developed to improve children's wellbeing by bringing focus on their life situations and daily activities based on consistent data from as many countries around the world as possible. Questionnaires were addressed to children from different age groups (children aged 8,10, and 12) in countries where the survey was conducted. Questionnaires were adapted to each age group by taking into account especially the number of questions and time necessary to answer. The questionnaires include a wide range of topics that cover various life domains and aspects of life related to children's wellbeing: Their house, people they live with, things they have, relationships with others, area where they live, their school, health and leisure time. In the present research, we used the answers recorded to questions included in the section addressing housing aspects.

Taking into account these aspects, in our study we used certain indicators regarding housing conditions, basic house amenities, household goods, and children's own goods. In this regard, in some analyses, it was necessary to exclude certain countries because they did not include in their survey the questions regarding these indicators. For instance, we noticed that only 12 countries included questions about basic housing amenities such as access to electricity, running water, and a toilet that flushes. Most of the countries participating in the study did not even collect data on indicators that probably do not 
represent a major problem for them. Questions related to conditions that meet the basic needs were included in questionnaires from countries such as: Albania, Brazil, Chile, Algeria, Hungary, India, Sri Lanka, Namibia, Nepal, Russia, Vietnam, and South Africa. Except two of them (Chile and Hungary), none are found in the category of high-income economies: 4 of them are included in the upper-middle-income economies group and 6 of them are found within the lower-middle-income economies category. Therefore, the analysis regarding the basic house amenities (within the third research objective) could be conducted solely on these countries.

The study aims to analyze children's satisfaction with the house they live in. Therefore, the dependent variable included in our research is the degree of satisfaction measured on an 11-point scale. To identify the factors that have an impact on the level of satisfaction with the house, the following independent variables were included in the research: bathroom, own room, place to study, computer, car, washing machine, access to the Internet and mobile phone. These independent variables were grouped into 4 categories: housing conditions, basic house amenities, household goods, and children's own goods. Descriptive statistics for each variable included in our research are presented in the results section below. Our research is structured into five sections: first, we present results on descriptive statistics for all variables included in our research; secondly, we present data regarding housing conditions and household goods based on the country category by income and by geographical region, then we analyze the impact of housing conditions and household goods on children's satisfaction with their house in 31 countries. Following that, we focus on the impact of house basic amenities on children's satisfaction with their house in 10 countries (lower- and upper-middle-income economies), and finally we investigate the indicators that have a significant impact on children's satisfaction with their house in 20 high-income economies.

\section{Results}

3.1. Descriptive Statistics: Dependent and Independent Variables

\subsubsection{Dependent Variable}

Our research aims to analyze children's overall satisfaction with their house. We used answers on an 11-point scale (from 0 -Not at all satisfied to 10-Totally satisfied) regarding the satisfaction with the house or flat where the children live. The mean value is 8.85 , with 2.01 standard deviation. In high-income economies, the mean value is 9.05 and in upper-middle and lower-middle income economies we registered lower values: 8.61 and 8.70, respectively. Between high-income countries and upper- and lower-middle-income economies, differences are statistically significant $(t=-30.33, p=0.000)$. As for countries by geographical region, the recorded values are the following: 9.18 for Europe and Central Asia, 8.49 for East Asia and Pacific region, 8.90 Latin America and the Caribbean, 9.07 for Middle East and North Africa, 8.75 for South Asia, and 8.69 Sub-Saharan Africa (all values are statistically different for all regions except for Latin America and the Caribbean; see Figure 1).

\subsubsection{Independent Variables}

As part of our research, we analyzed the impact of some housing quality indicators on children overall satisfaction with the house they live in. Indicators are categorized into four groups: housing conditions, basic house amenities, household goods, and children's own goods. Following the descriptive analysis of the data, some of the indicators in these categories ware transformed into dummy variables (see Table 3). Regarding the indicators from the basic house amenities group, they are presented in the analysis based on data from 10 countries from upper- and lower-middle-income economies.

\subsection{Bivariate Statistics: Housing Conditions, Household Goods, and Children's Own Goods by Type of Country}

In this section we present the results on housing conditions, household goods, and children's own goods, following data by type of country by income and by regions. 
There is a strong association between the two variables related to country category (chi-square $=90202.96, \mathrm{df} 10, p=0.000$ ). Most countries from Europe and Central Asia are included in the high-income economies (adjusted residual $=160.4$ ) and those from South Asia are included in lower-middle-income economies (adjusted residual $=223.2$ ). Countries from Sub-Saharan Africa are mostly categorized as upper-middle-income economies (adjusted residual $=137.7$ ). There are also association relations for the other geographical regions and income categories.

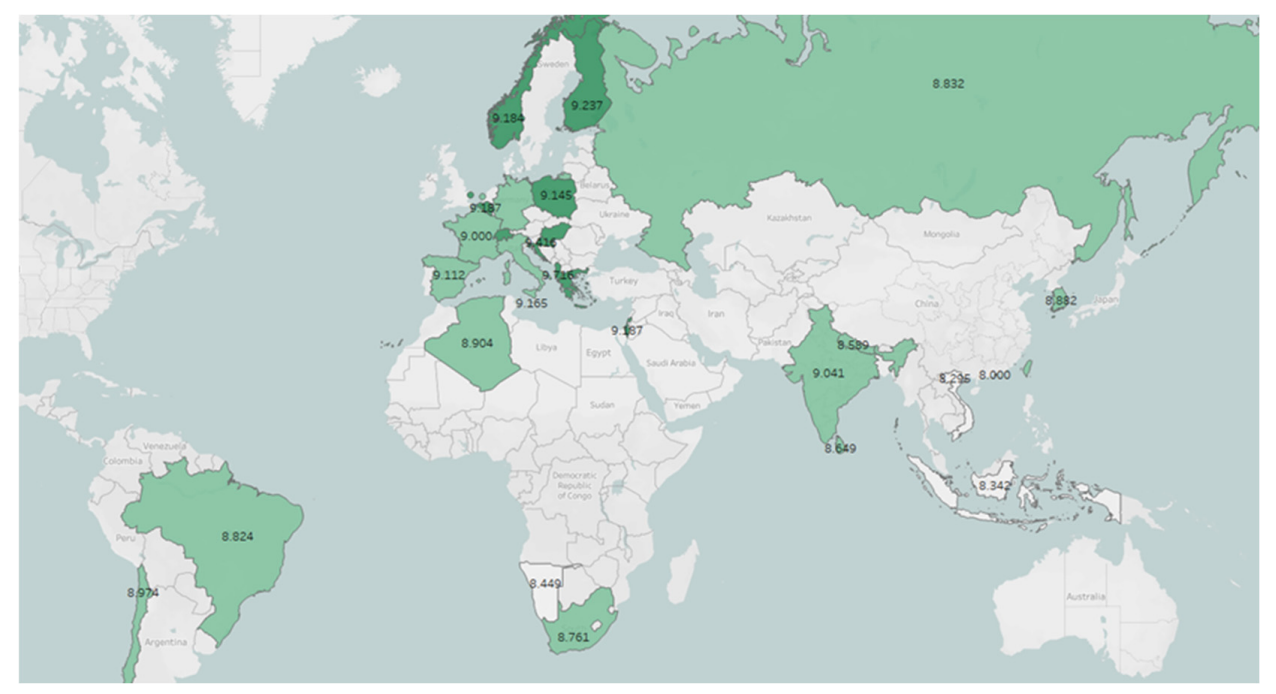

Figure 1. Children's satisfaction with their house (scale 0-10). Mean values by countries (map developed using Tableau).

The tests' results show significant differences regarding all indicators registered between high-income economies, upper-middle-income economies, and lower-middle income economies (see Tables 4 and 5). Both in terms of housing conditions and household goods, a higher percentage of items present in the household is registered for high-income countries and lower values in upper-middle-income economies, and even lower in lowermiddle-income economies. The greatest differences are registered regarding the availability of the bathroom in the house: $15.6 \%$ of children from lower-middle-income countries do not have an indoor bathroom, while only $0.5 \%$ of children from high-income economies and $7.1 \%$ from those in upper-middle-income countries report this problem. Large differences are recorded between high-income regions and lower- and upper-middle-income economies regarding the other indicators: PC, washing machine, car and Internet access. The percentage of children from high-income countries who report that they do not have these goods in their house is below 10, while for the countries from the other two categories, the values are over 30 .

Values recorded in countries included by geographic region categories also show significant differences (see Tables 6 and 7). Fewer facilities in the house and household goods are found in South Asia and Sub-Saharan Africa region, followed by East Asian and Pacific regions. With regard to access to most amenities, respectively high percentages regarding the presence of goods in the household are found in the case of children from countries in Europe and Central Asia. The greatest differences are registered regarding the access to a bathroom for children in South Asia compared to children in other regions, and the presence of a washing machine and a PC in the household.

\subsection{Predictors of Children's Overall Satisfaction with Their House}

We developed a regression model (using enter method) to analyze the impact of housing conditions, household goods, and children's own goods on their overall satisfaction with their house (see Table 8). The multicollinearity test indicates that the possible correlations between the independent variables do not pose problems to the explanatory model. 
Table 3. Descriptive statistics: independent variables.

\begin{tabular}{|c|c|c|}
\hline Indicator & Question in the Survey & Type of Variable and Descriptive Statistics \\
\hline \multicolumn{3}{|l|}{ HOUSING CONDITIONS } \\
\hline Bathroom & How many bathrooms are in your home? & $\begin{array}{l}\text { Initial variable: ordinal (answers: 'none', 'one', 'two', 'more than two') } \\
\text { Transformed into dichotomous variable: } \\
1=\text { yes, there is at least one bathroom in the house }(95.4 \%) \\
\quad 0=\text { no, there is no bathroom }(4.6 \%)\end{array}$ \\
\hline Own room & Do you sleep in your own room or do you share a room? & $\begin{array}{l}\text { Dichotomous variable: } \\
\begin{array}{l}1=\text { 'sleep in my own room' }(57.7 \%) \\
0=\text { 'sleep in a shared room' }(42.3 \%)\end{array}\end{array}$ \\
\hline Place to study & Is there a place in your home where you can study? & $\begin{array}{c}\text { Dichotomous variable: } \\
1=\text { yes }(85.1 \%) ; 0=\text { no }(14.9 \%) \\
\text { Excluded from the analysis answers 'Not sure' }(5.4 \%)\end{array}$ \\
\hline \multicolumn{3}{|l|}{ HOUSEHOLD GOODS } \\
\hline Computer & How many computers do your family own? & $\begin{array}{l}\text { Initial variable: ordinal (answers: 'none', 'one', 'two', 'more than two') } \\
\text { Transformed into dichotomous variable: } \\
\qquad 1=\text { yes }(82.3 \%) ; 0=\text { no }(17.7 \%) \\
\text { Initial variable: ordinal (answers: 'none', 'one' 'two' 'three or more') }\end{array}$ \\
\hline A car/van/motorbike/etc. & How many cars, vans or trucks does your family have? & $\begin{array}{l}\text { Transformed into dichotomous variable: } \\
1=\text { yes }(73.9 \%) ; 0=\text { no }(26.1 \%)\end{array}$ \\
\hline Washing machine & Does your home have a washing machine? & $\begin{array}{c}\text { Dichotomous variable: } \\
1=\text { yes }(81.9 \%) ; 0=\text { no }(18.1 \%)\end{array}$ \\
\hline \multicolumn{3}{|l|}{ CHILDREN'S OWN GOODS } \\
\hline Access to the Internet & Which of the following do you have? & $\begin{array}{c}\text { Dichotomous variable: } \\
1=\text { yes }(78.1 \%) ; 0=\text { no }(21.9 \%)\end{array}$ \\
\hline Mobile phone & Which of the following do you have? & $\begin{array}{c}\text { Dichotomous variable: } \\
1=\text { yes }(76.3 \%) ; 0=\text { no }(23.7 \%)\end{array}$ \\
\hline
\end{tabular}


Table 4 . Housing conditions by country category by income.

\begin{tabular}{ccccccc}
\hline & \multicolumn{2}{c}{ Bathroom } & \multicolumn{2}{c}{ Own Room } & \multicolumn{2}{c}{ Place to Study } \\
\hline & No $\%$ & Yes $\%$ & No $\%$ & Yes $\%$ & No\% & Yes $\%$ \\
high-income economies & 0.5 & 99.5 & 35.8 & 64.2 & 4.4 & 95.6 \\
upper-middle-income economies & 7.1 & 92.9 & 45.3 & 54.7 & 28.4 & 71.6 \\
lower-middle income economies & 15.6 & 84.4 & 61.4 & 38.6 & 20.7 & 79.3 \\
\hline Results of chi-square significance test & $5059.45, \mathrm{df} 2, p=0.000$ & $2466.48, \mathrm{df} 2, p=0.000$ & $8229.98, \mathrm{df} 2, p=0.000$ \\
\hline
\end{tabular}

Table 5. Household goods and child's own goods by country category by income.

\begin{tabular}{|c|c|c|c|c|c|c|c|c|c|c|}
\hline & \multicolumn{2}{|c|}{ PC } & \multicolumn{2}{|c|}{ Washing Machine } & \multicolumn{2}{|c|}{ Car } & \multicolumn{2}{|c|}{ Internet Access } & \multicolumn{2}{|c|}{ Mobile Phone } \\
\hline & $\mathrm{No} \%$ & Yes\% & $\mathrm{No} \%$ & Yes $\%$ & $\mathrm{No} \%$ & Yes\% & $\mathrm{No} \%$ & Yes $\%$ & $\mathrm{No} \%$ & Yes $\%$ \\
\hline high-income economies & 2.8 & 97.2 & 1.7 & 98.3 & 9.3 & 90.7 & 4.1 & 95.9 & 16.2 & 83.8 \\
\hline upper-middle-income economies & 30.1 & 69.9 & 28.9 & 71.1 & 43.5 & 56.5 & 40.0 & 60.0 & 24.5 & 75.5 \\
\hline lower-middle income economies & 46.3 & 53.7 & 54.9 & 45.1 & 49.4 & 50.6 & 46.5 & 53.5 & 53.1 & 46.9 \\
\hline Results of chi-square significance test & \multicolumn{2}{|c|}{$\begin{array}{c}16,090.2 \mathrm{df} 2 \\
p=0.000\end{array}$} & \multicolumn{2}{|c|}{$\begin{array}{c}17,881.91, \mathrm{df} 2 \\
p=0.000\end{array}$} & \multicolumn{2}{|c|}{$\begin{array}{c}14,351.84, \text { df } 2 \\
p=0.000\end{array}$} & \multicolumn{2}{|c|}{$\begin{array}{c}17,665.67 \mathrm{df} 2 \\
p=0.000\end{array}$} & \multicolumn{2}{|c|}{$\begin{array}{c}6376.43, \mathrm{df} 2 \\
p=0.000\end{array}$} \\
\hline
\end{tabular}

Table 6. Housing conditions by country category by geographic region.

\begin{tabular}{|c|c|c|c|c|c|c|}
\hline & \multicolumn{2}{|c|}{ Bathroom } & \multicolumn{2}{|c|}{ Own Room } & \multicolumn{2}{|c|}{ Place to Study } \\
\hline & $\mathrm{No} \%$ & Yes\% & $\mathrm{No} \%$ & Yes\% & $\mathrm{No} \%$ & Yes\% \\
\hline Europe and Central Asia & 0.7 & 99.3 & 33.4 & 66.6 & 5.3 & 94.7 \\
\hline East Asia and Pacific & 4.0 & 96.0 & 41.3 & 58.7 & 23.4 & 76.6 \\
\hline Latin America and the Caribbean & 1.1 & 98.9 & 42.0 & 58.0 & 6.1 & 93.9 \\
\hline Middle East and North Africa & 2.6 & 97.4 & 53.7 & 46.3 & 6.3 & 93.7 \\
\hline South Asia & 20.4 & 79.6 & 67.0 & 33.0 & 28.3 & 71.7 \\
\hline Sub-Saharan Africa & 14.5 & 85.5 & 53.0 & 47.0 & 22.4 & 77.6 \\
\hline Results of chi-square significance test & \multicolumn{2}{|c|}{6488.16, df $5, p=0.000$} & \multicolumn{2}{|c|}{3415.78, df $5, p=0.000$} & \multicolumn{2}{|c|}{$5607.31, \mathrm{df} 5, p=0.000$} \\
\hline
\end{tabular}

Table 7. Household goods and child's own goods by country category by geographic region.

\begin{tabular}{|c|c|c|c|c|c|c|c|c|c|c|}
\hline & \multicolumn{2}{|c|}{ PC } & \multicolumn{2}{|c|}{ Washing Machine } & \multicolumn{2}{|c|}{ Car } & \multicolumn{2}{|c|}{ Internet Access } & \multicolumn{2}{|c|}{ Mobile Phone } \\
\hline & $\mathrm{No} \%$ & Yes\% & $\mathrm{No} \%$ & Yes\% & $\mathrm{No} \%$ & Yes\% & $\mathrm{No} \%$ & Yes\% & $\mathrm{No} \%$ & Yes $\%$ \\
\hline Europe and Central Asia & 3.6 & 96.4 & 9.4 & 90.6 & 2.3 & 97.7 & 3.9 & 96.1 & 16.9 & 83.1 \\
\hline East Asia and Pacific & 25.5 & 74.5 & 41.2 & 58.8 & 25.3 & 74.7 & 34.7 & 65.3 & 20.6 & 79.4 \\
\hline Latin America and the Caribbean & 14.9 & 85.1 & 24.2 & 75.8 & 3.2 & 96.8 & 7.4 & 92.6 & 12.0 & 88.0 \\
\hline Middle East and North Africa & 9.6 & 90.4 & 17.0 & 83.0 & 2.4 & 97.6 & 18.5 & 81.5 & 27.0 & 73.0 \\
\hline South Asia & 54.7 & 45.3 & 61.1 & 38.9 & 70.3 & 29.7 & 54.1 & 45.9 & 61.8 & 38.2 \\
\hline Sub-Saharan Africa & 26.2 & 73.8 & 24.0 & 76.0 & 26.3 & 73.7 & 34.2 & 65.8 & 33.2 & 66.8 \\
\hline $\begin{array}{l}\text { Results of chi-square } \\
\text { significance test }\end{array}$ & \multicolumn{2}{|c|}{$\begin{array}{c}12,377.58, \text { df } 5 \\
p=0.000\end{array}$} & \multicolumn{2}{|c|}{$\begin{array}{l}12,248.6, \mathrm{df} 5 \\
p=0.000\end{array}$} & \multicolumn{2}{|c|}{$\begin{array}{c}19,138.18, \text { df } 5 \\
p=0.000\end{array}$} & \multicolumn{2}{|c|}{$\begin{array}{c}13,932.75, \text { df } 5 \\
p=0.000\end{array}$} & \multicolumn{2}{|c|}{$\begin{array}{c}6791.04, \text { df } 5 \\
p=0.000\end{array}$} \\
\hline
\end{tabular}

All indicators included in the model, except of washing machine and mobile phone, have a significant impact on children's satisfaction with their house. Across all the indicators, having a place to study has the greatest importance on children's satisfaction with their house. Compared to the values recorded for other facilities in the house or household goods, having a place to study makes children positively appreciate their home. When the indicator referring to the access to internet was included in the model, the values for the other indicators decreased, and both the possession of a washing machine and of a mobile phone became non-significant. Internet access, the possession of a family car, bathroom, a PC, and children's own room are also household conditions and goods that have a positive impact on children's satisfaction. 
Table 8. Regression model on children's satisfaction with the house or flat they live in. Analysis on 31 countries.

\begin{tabular}{|c|c|c|c|c|}
\hline & \multicolumn{2}{|c|}{ Unstandardized Coefficients } & \multirow[t]{2}{*}{$\mathbf{t}$} & \multirow[t]{2}{*}{ Sig. } \\
\hline & B & Std. Error & & \\
\hline \multicolumn{5}{|c|}{ MODEL 1} \\
\hline \multicolumn{5}{|c|}{$\mathrm{R}=0.159 ;$ Adjusted R Square $=0.025 ;$ Std. Error of the Estimate $=1.904$} \\
\hline Bathroom & 0.429 & 0.035 & 12.102 & 0.000 \\
\hline Own room & 0.089 & 0.015 & 6.017 & 0.000 \\
\hline Place to study & 0.747 & 0.020 & 36.503 & 0.000 \\
\hline \multicolumn{5}{|c|}{ MODEL 2} \\
\hline \multicolumn{5}{|c|}{$\mathrm{R}=0.179 ;$ Adjusted R Square $=0.032 ;$ Std. Error of the Estimate $=1.897$} \\
\hline Bathroom & 0.254 & 0.037 & 6.950 & 0.000 \\
\hline Own room & 0.060 & 0.015 & 4.001 & 0.000 \\
\hline Place to study & 0.588 & 0.022 & 27.069 & 0.000 \\
\hline PC & 0.157 & 0.023 & 6.811 & 0.000 \\
\hline Car & 0.279 & 0.019 & 14.615 & 0.000 \\
\hline Washing machine & 0.086 & 0.023 & 3.728 & 0.000 \\
\hline \multicolumn{5}{|c|}{ MODEL 3} \\
\hline \multicolumn{5}{|c|}{$\mathrm{R}=0.185 ;$ Adjusted R Square $=0.034 ;$ Std. Error of the Estimate $=1.895$} \\
\hline Bathroom & 0.232 & 0.037 & 6.329 & 0.000 \\
\hline Own room & 0.060 & 0.015 & 4.033 & 0.000 \\
\hline Place to study & 0.545 & 0.022 & 24.784 & 0.000 \\
\hline PC & 0.089 & 0.024 & 3.766 & 0.000 \\
\hline Car & 0.234 & 0.019 & 12.055 & 0.000 \\
\hline Washing machine & 0.032 & 0.023 & 1.379 & 0.168 \\
\hline Internet access & 0.267 & 0.022 & 12.395 & 0.000 \\
\hline Mobile phone & -0.022 & 0.018 & -1.193 & 0.233 \\
\hline
\end{tabular}

3.4. The Impact of House Basic Amenities on Children's Satisfaction with Their House. Analysis in 10 Lower-and Upper-Middle-Income Economies

In this section we present the results regarding children's satisfaction with their house in 10 selected countries from upper- and lower-middle-income categories. According to the geographic region, 35.8\% cases are from countries in Sub-Saharan Africa, $24.6 \%$ are from countries in South Asia, 16.4 are from Europe and Central Asia, 8.7 are from Middle East and North Africa, 7.6 are from East Asia and Pacific, and 6.9 are from Latin America and the Caribbean. We selected the 10 countries because variables regarding basic house amenities were included in the surveys conducted at national level. Therefore, in our regression model we added these variables referring to access to electricity, running water, and a toilet that flushes. The data on these indicators are presented in Table 9.

Table 9. Descriptive statistics: independent variables Basic amenities.

\begin{tabular}{|c|c|c|}
\hline Indicator & Question in the Survey & Type of Variable and Descriptive Statistics \\
\hline \multicolumn{3}{|c|}{ BASIC HOUSE AMENITIES } \\
\hline Electricity & Does your home have electricity? & $\begin{array}{l}\text { Initial variable: ordinal (answers: 'Not at all', 'Some of the } \\
\text { time', 'All of the time') } \\
\text { Transformed into dichotomous variable: } \\
1=\text { yes }(96.9 \%) ; 0=\text { no }(3.1 \%) \\
\text { Dichotomous variable: }\end{array}$ \\
\hline Running water & Does your home have running water? & $\begin{array}{l}1=\text { yes }(85.0 \%) ; 0=\text { no }(15.0 \%) \\
\text { Excluded from the analysis answers 'Not sure' }(4.1 \%) \\
\text { Dichotomous variable: }\end{array}$ \\
\hline Toilet that flushes & Does your home have a toilet that flushes? & $\begin{array}{l}1=\text { yes }(77.0 \%) ; 0=\text { no }(23.0 \%) \\
\text { Excluded from the analysis answers 'Not sure' }(3.8 \%)\end{array}$ \\
\hline
\end{tabular}


Data show significant differences across geographical regions (see Table 10). Regarding the access to electricity, children from Sub-Saharan Africa most face the problem of access to basic house amenities in the house where they live. We registered even more worrying values regarding the access to a toilet for children in South Asian countries. Almost half of them do not have an indoor toilet that flushes. The highest percentages of children who have access to basic house amenities are recorded in countries from Latin America and the Caribbean, and Europe and Central Asia.

Table 10. Basic house amenities by country category by geographic region.

\begin{tabular}{|c|c|c|c|c|c|c|}
\hline & \multicolumn{2}{|c|}{ Electricity } & \multicolumn{2}{|c|}{ Running Water } & \multicolumn{2}{|c|}{ Toilet that Flushes } \\
\hline & $\mathrm{No} \%$ & Yes\% & $\mathrm{No} \%$ & Yes\% & $\mathrm{No} \%$ & Yes\% \\
\hline Europe and Central Asia & 1.3 & 98.7 & 4.4 & 95.6 & 5.7 & 94.3 \\
\hline East Asia and Pacific & 1.1 & 98.9 & 22.4 & 77.6 & 21.6 & 78.4 \\
\hline Latin America and the Caribbean & 0.9 & 99.1 & 0.1 & 99.9 & 0.9 & 99.1 \\
\hline Middle East and North Africa & 1.2 & 98.8 & 7.1 & 92.9 & 14.6 & 85.4 \\
\hline South Asia & 1.6 & 98.4 & 17.9 & 82.1 & 46.4 & 53.6 \\
\hline Sub-Saharan Africa & 6.2 & 93.8 & 21.5 & 78.5 & 21.6 & 78.4 \\
\hline Results of chi-square significance test & \multicolumn{2}{|c|}{469.47 , df $5, p=0.000$} & \multicolumn{2}{|c|}{1165.95, df $5, p=0.000$} & \multicolumn{2}{|c|}{2984.48, df $5, p=0.000$} \\
\hline
\end{tabular}

We added indicators regarding housing conditions, household goods, and children's own goods and house basic amenities in a regression model (using method enter) to highlight which of these categories of indicators have a significant impact on children's satisfaction with their house in countries included in lower- and upper-middle-income economies (see Table 11). We tested the possible multicollinearity issues for this model, and the test results did not indicate such problems.

The model shows the same indicators as having the highest predictive power as those revealed by the previous one. Having a place to study and access to Internet mainly determine the satisfaction with the house. Regarding the indicators from basic house amenities category, only access to running water has a significant impact. It is interesting that several indicators are not significant in this model (own room, washing machine, phone, electricity, and flushing toilet). In addition to those three indicators forementioned, having a bathroom in the house, a PC, and a car also have a significant impact on children's satisfaction with the house they live in.

\subsection{Factors That Explain Children's Satisfaction with Their House in 20 High-Income Economies}

In this final section we analyze the impact of housing conditions, household goods, and children's own goods on their overall satisfaction with the house they live in for 20 countries from the high-income category (see regression model in Table 12). No multicollinearity problems were identified for this model.

All indicators included in the model have a significant impact on children's satisfaction with their house, and the explanatory power of the model is higher than that of the ones previously presented. The satisfaction with the house in which children from the countries included in the high-income regions live is explained by the availability of a place for study, the bathroom in the house and the availability of a car, washing machine, PC, internet access, own room and phone. It is interesting that the internet access does not register high values as in previously presented models. 
Table 11. Regression model on children's satisfaction with the house or flat where they live. Analysis on 10 lower- and upper-middle-income countries.

\begin{tabular}{|c|c|c|c|c|}
\hline & \multicolumn{2}{|c|}{ Unstandardized Coefficients } & \multirow[t]{2}{*}{$\mathbf{t}$} & \multirow[t]{2}{*}{ Sig. } \\
\hline & B & Std. Error & & \\
\hline \multicolumn{5}{|c|}{ MODEL 1} \\
\hline \multicolumn{5}{|c|}{$\mathrm{R}=0.124 ;$ Adjusted R Square $=0.015 ;$ Std. Error of the Estimate $=2.079$} \\
\hline Bathroom & 0.299 & 0.053 & 5.617 & 0.000 \\
\hline Own room & 0.014 & 0.033 & 0.427 & 0.669 \\
\hline Place to study & 0.572 & 0.043 & 13.359 & 0.000 \\
\hline \multicolumn{5}{|c|}{ MODEL 2} \\
\hline \multicolumn{5}{|c|}{$\mathrm{R}=0.137 ;$ Adjusted $\mathrm{R}$ Square $=0.018 ;$ Std. Error of the Estimate $=2.076$} \\
\hline Bathroom & 0.190 & 0.055 & 3.436 & 0.001 \\
\hline Own room & -0.024 & 0.033 & -0.707 & 0.480 \\
\hline Place to study & 0.497 & 0.044 & 11.267 & 0.000 \\
\hline PC & 0.188 & 0.041 & 4.616 & 0.000 \\
\hline Washing machine & 0.048 & 0.041 & 1.178 & 0.239 \\
\hline Car & 0.134 & 0.037 & 3.592 & 0.000 \\
\hline \multicolumn{5}{|c|}{ MODEL 3} \\
\hline \multicolumn{5}{|c|}{$\mathrm{R}=0.150 ;$ Adjusted R Square $=0.022 ;$ Std. Error of the Estimate $=2.072$} \\
\hline Bathroom & 0.151 & 0.056 & 2.723 & 0.006 \\
\hline Own room & -0.026 & 0.033 & -0.768 & 0.443 \\
\hline Place to study & 0.453 & 0.044 & 10.208 & 0.000 \\
\hline PC & 0.121 & 0.041 & 2.908 & 0.004 \\
\hline Washing machine & -0.007 & 0.042 & -0.160 & 0.873 \\
\hline Car & 0.101 & 0.038 & 2.669 & 0.008 \\
\hline Internet access & 0.325 & 0.041 & 7.909 & 0.000 \\
\hline Mobile phone & -0.037 & 0.038 & -0.993 & 0.321 \\
\hline \multicolumn{5}{|c|}{ MODEL 4} \\
\hline \multicolumn{5}{|c|}{$\mathrm{R}=0.152 ;$ Adjusted R Square $=0.023 ;$ Std. Error of the Estimate $=2.071$} \\
\hline Bathroom & 0.143 & 0.057 & 2.511 & 0.012 \\
\hline Own room & -0.023 & 0.033 & -0.674 & 0.500 \\
\hline Place to study & 0.440 & 0.045 & 9.855 & 0.000 \\
\hline PC & 0.120 & 0.042 & 2.889 & 0.004 \\
\hline Washing machine & -0.001 & 0.043 & -0.013 & 0.989 \\
\hline Car & 0.102 & 0.038 & 2.701 & 0.007 \\
\hline Internet access & 0.321 & 0.041 & 7.764 & 0.000 \\
\hline Mobile phone & -0.034 & 0.038 & -0.899 & 0.369 \\
\hline Electricity & 0.031 & 0.136 & 0.228 & 0.819 \\
\hline Running water & 0.192 & 0.053 & 3.635 & 0.000 \\
\hline Toilet flushes & -0.075 & 0.048 & -1.564 & 0.118 \\
\hline
\end{tabular}


Table 12. Regression model on children's satisfaction with the house or flat where they live. Analysis on 20 high-income countries.

\begin{tabular}{|c|c|c|c|c|}
\hline & \multicolumn{2}{|c|}{ Unstandardized Coefficients } & \multirow[t]{2}{*}{$\mathbf{t}$} & \multirow[t]{2}{*}{ Sig. } \\
\hline & B & Std. Error & & \\
\hline \multicolumn{5}{|c|}{ MODEL 1} \\
\hline \multicolumn{5}{|c|}{$\mathrm{R}=0.209 ;$ Adjusted R Square $=0.043 ;$ Std. Error of the Estimate $=1.589$} \\
\hline Bathroom & 1.365 & 0.126 & 10.790 & 0.000 \\
\hline Own room & 0.218 & 0.018 & 12.393 & 0.000 \\
\hline Place to study & 1.484 & 0.042 & 35.113 & 0.000 \\
\hline \multicolumn{5}{|c|}{ MODEL 2} \\
\hline \multicolumn{5}{|c|}{$\mathrm{R}=0.237 ;$ Adjusted R Square $=0.056 ;$ Std. Error of the Estimate $=1.579$} \\
\hline Bathroom & 1.118 & 0.126 & 8.858 & 0.000 \\
\hline Own room & 0.175 & 0.018 & 9.924 & 0.000 \\
\hline Place to study & 1.429 & 0.042 & 33.962 & 0.000 \\
\hline PC & 0.424 & 0.055 & 7.709 & 0.000 \\
\hline Washing machine & 0.384 & 0.065 & 5.879 & 0.000 \\
\hline Car & 0.552 & 0.030 & 18.301 & 0.000 \\
\hline \multicolumn{5}{|c|}{ MODEL 3} \\
\hline \multicolumn{5}{|c|}{$\mathrm{R}=0.240 ;$ Adjusted R Square $=0.058 ;$ Std. Error of the Estimate $=1.577$} \\
\hline Bathroom & 1.110 & 0.126 & 8.805 & 0.000 \\
\hline Own room & 0.174 & 0.018 & 9.858 & 0.000 \\
\hline Place to study & 1.423 & 0.042 & 33.791 & 0.000 \\
\hline PC & 0.368 & 0.056 & 6.614 & 0.000 \\
\hline Washing machine & 0.383 & 0.065 & 5.862 & 0.000 \\
\hline Car & 0.544 & 0.030 & 18.017 & 0.000 \\
\hline Internet access & 0.328 & 0.045 & 7.270 & 0.000 \\
\hline Mobile phone & -0.108 & 0.023 & -4.592 & 0.000 \\
\hline
\end{tabular}

\section{Discussion}

Our research analyzes children's perceptions and satisfaction with their house. Starting from the consideration that there is a strong connection between children's house and their home, the study focuses in determining the main housing conditions and household goods that make children positively appreciate the house where they live. Home is the place where children grow up, where they develop, and where they learn and live with their family. For a proper development of children, a home needs to be a healthy environment. The house the children live in is just as important. Housing conditions, household goods, and other material circumstances related to the house are also part of the environment where the child develops.

We consider that it is very important to approach housing conditions within the broad context of sustainable development and wellbeing and to investigate how they perceive their needs are satisfied in this regard. Among others, these needs also play an essential role for an adequate development. Children's subjective assessment of their housing provides an insight on their living environment, and therefore on their livability. Our study focuses on children, and a strength of our research is that we approach children's satisfaction with their house by using self-reported data. We consider that our results are interesting and provide an extended approach of children's satisfaction and perception with their house. The results of the study are in line with those that argue that satisfaction with the house depends on material conditions $[26,27]$. However, another relevant indicator in our study supports those approaches having a broader view on housing, namely, those that take into account the major role of home learning environment.

We followed in our analysis the material setting described by children regarding their homes. It is obvious that these material circumstances of housing are strongly related to a wider context, namely, to the characteristics of countries and areas where children live. The type and style of houses, housing conditions, and facilities found in the household 
are all explained by the specifics of the geographic regions, the type of land, the natural resources available in the area, the socio-cultural context of the country, and, last but not least, the financial situation and economic context of the country. All indicators included in our research show significant differences both regarding the category of countries by income and by geographical region. Therefore, there are significant differences between countries that can be explained by referring, on one hand, to the economic context of the country, and on the other hand, to the area where the country is located. These differences reflect variations in financial constraints as well as in socio-cultural norms.

The main subject approached in our paper is influenced by the context of countries where data was collected. The analysis was conducted in 31 countries from all regions around the world classified into three categories by income: high, lower-middle, and upper-middle. By including in this model the indicators regarding housing, we wanted to go beyond the context of the country where children live, and to capture aspects related to housing conditions that explain children's satisfaction with their house. The results indicate that children's satisfaction is explained by several indicators related to the material situation of the family and household conditions, such as possession of a car, access to bathroom, and having a PC. Alongside these indicators, the perception of housing conditions and household goods also prove to have an impact on children's satisfaction with the house. These results argue the role that the house has in ensuring livability conditions. To capture certain differences regarding the category to which the country belongs, we also conducted explanatory models for children's satisfaction with their house in countries included in lower-middle and upper-middle economies, and for children from high-income countries.

As the latest report on the Children's Worlds project states, a limited access to information may put children at risk of social exclusion. "Information poverty may constitute a new form of disadvantage experienced by children in lower-income countries, potentially affecting their possible future directions" [58] (p. 16). Among all indicators related to housing conditions, household goods, and children's own goods included in our regression model, having a place to study and access to internet presents the greatest impact on children's satisfaction with their house. The results suggest that children's satisfaction with the house they live in is related to their home environment, an environment that ensures them access to information and knowledge. Having a place to study could be depicted as an indicator of a supportive and stimulative home environment toward learning. Only in this context can the child properly and harmoniously develop. Moreover, by following this path we can reach truly sustainable societies, where the focus is not only on material circumstances, but also on ensuring a healthy life and promoting wellbeing of all at all ages.

Data suggest that children's satisfaction with the house they live in relates to livability, in the sense that it is obvious that basic external conditions must be ensured in terms of housing, thus it is equally important how children position themselves towards these conditions, because there is a subjective filter for the assessment of living environment [9]. In the case of children's satisfaction with their house, it is important how the house offers and ensures them livability conditions.

Other significant indicators in our model refer to having a bathroom and a car. These indicators rather reflect the material condition of the children's family and their financial situation. At the same time, these two indicators, and especially the access to bathroom, indicate the link between the level of satisfaction and the cultural context specific to the country where the child lives, respectively the economic characteristics at the level of the geographical regions. Having a PC in the household and their own room are also significant indicators, although the recorded values are quite low.

In the study we followed the analysis of the impact that basic house amenities have on children's satisfaction with their house. The analysis was conducted on data from 10 lower- and upper-middle-income economies, as these countries included in their survey questions regarding basic household facilities. As in the previous model, in the case of children in these countries, indicators referring to housing conditions and household goods are significant, and having a place to study and access to Internet have the highest values. 
Therefore, also for these children, the access to information represents an important need that must be met by ensuring optimal household conditions for child's development. We note that in this model, internet access has a stronger impact on children's satisfaction with the home than in the model conducted on 31 countries. If we think that information poverty is one of the conditions that lead to social exclusion, the results obtained become even more consistent. It is understandable why it is so important for children in lower- and upper-middle-income countries to have internet access at home.

From the indicators related to basic house amenities added in this model, solely the one referring to indoor running water has a significant impact on children's satisfaction with their house. It is most likely that this indicator is related to the characteristics of the geographical region, as problems regarding the access to basic house amenities such as access to water are encountered in areas such as Sub-Saharan Africa, South Asia, and East Asia and Pacific.

In the case of children from the 10 lower- and upper-middle-income economies, having their own room, a mobile phone, a washing machine in the house, electricity, and a toilet that flushes have no significant impact on children's satisfaction with the house they live in.

In the model, based on data from 20 high-income countries, all indicators regarding housing conditions, household goods, and children's own goods have a significant impact on children's satisfaction with their house. We note that the strongest impact on children's satisfaction is registered in the case of having a place to study. Therefore, the model identifies the same indicator as the most important one. For children from countries included in the high-income category, ensuring optimal conditions for learning is the most important thing regarding living conditions. It is interesting that the indicator regarding the bathroom proves to have a strong impact for children from high-income countries. Only $0.5 \%$ of children in this category of countries report that they do not have a bathroom in the house. In this sense, this indicator proves to have a high degree of containment. For children in high-income economies, not having a bathroom in the house proves to mean a great deal in ensuring their overall satisfaction with the house. The absence of an indoor bathroom can be a determinant factor of social exclusion of these children. Having a car is also an important indicator regarding children's satisfaction with the house. Thus, this indicator, like the other ones that prove to have a significant impact, shows that satisfaction with the house is related to the financial context of the family. Having a PC, a washing machine and internet access have a significant impact on children's satisfaction with their house. We note that, compared to our previous models, household goods are more important.

All indicators introduced in the explanatory models regarding house satisfaction with significant impact are strongly related to the socio-economic status of the family. In this sense, we can say that the research results support those arguments according to which the appreciation of housing conditions is determined by the family wealth. At the same time, we note that the indicator with the greatest impact is the one referring to having a place to study, regardless of country category. Of all indicators included in the model, this one is not directly linked to the material situation of the family, but rather refers to the home environment, from the perspective of an environment that supports learning.

The research carried out encounters certain limitations, most of them framed within the disadvantages of the secondary data analysis. To a larger extent, the housing indicators used relates to the socio-economic status of the family. To be able to capture in more detail the relationship between house satisfaction and family affluence, it could have been of help to introduce also other indicators in the model, such as family income, parental education, occupational status, etc. Furthermore, due to the lack of data, the analysis on the impact of household amenities could not be performed in all 31 countries. This limitation of the research is due to that some indicators used in our study were not included in all countries surveys.

The factor that recorded the highest values in the regression models regarding house satisfaction is the place to study. The results suggest that an important role in determining children's satisfaction with their house is played by the environment where they live 
and the way the home represents an environment that supports them in their personal development. The research could be continued by adding other indicators related to the home environment (learning, study, literacy, social environments) and to observe to what extent those ones reduce the impact of indicators regarding housing conditions and household goods.

\section{Conclusions}

Research has demonstrated the interconnection between housing and adult outcomes and wellbeing. Hence, these studies have opened the path to investigate the relationship between house environment and children's wellbeing. The assessment of housing conditions as an indicator of children's wellbeing and their proper development sheds light over children's needs. A more thoroughly investigation in this regard clarifies the direction on which we have to intervene for a proper development for children and thereby ensure sustainability. Societies are responsible to do their best to provide decent living conditions for all people to reduce inequalities.

The material conditions regarding housing are influenced by the characteristics of countries from different geographical areas and different socio-economic and cultural situations. Our research presents such differences in housing conditions and household goods between categories of countries included in the study. We aimed to identify the contribution of housing conditions and household goods on children's satisfaction with their house in countries all around the world. Research results confirm that satisfaction with the house is linked to material conditions; however, it is also shaped by the way children perceive housing conditions and household goods. This perception defines their home environment and provides livability conditions. The main indicator that influences the level of children's satisfaction with the house where they live is the availability of a space for study. The results fall within the main statements of the livability theory, namely, that external conditions are rather filtered by the subjective assessment of children regarding their living environment and therefore it is important how children relate to the conditions and goods within the household.

Author Contributions: Conceptualization, C.B., S.S., R.B. and C.M.; methodology, C.B., S.S. and R.B.; formal analysis, C.B., S.S. and R.B.; writing—original draft preparation, C.B., S.S., R.B. and C.M.; writing-review and editing, C.B., S.S., R.B. and C.M. All authors have read and agreed to the published version of the manuscript.

Funding: The research Children's Worlds: International Survey of Children's Well-Being (ISCWeb), third wave was supported by JACOBS FOUNDATION, SWITZERLAND.

Institutional Review Board Statement: In our research we used secondary data analysis. The methodology of the initial study that is the source of the data used in our research, included receiving the consent of parents and students participating in the study. Obtaining the consent was the responsibility of each country participating in the study, by applying their national legislation.

Informed Consent Statement: Informed consent was obtained from all subjects involved in the study.

Data Availability Statement: Children's Worlds International datasets for each wave of data collection are available online at: https: / / isciweb.org/the-data/access-our-dataset/ (accessed on 25 July 2021). Datasets analyzed for this research are from the third wave of the Children's Worlds project: An international survey of children's lives and well-being). The access to this dataset was facilitated by Claudia Bacter as a member of the Romanian project team. The contribution of Claudia Bacter was partially supported by Foundation Botnar, Switzerland, within the project "Child well-being in Romania".

Acknowledgments: The data used in this publication come from the third wave of Children's Worlds project: An international survey of children's lives and well-being (www.isciweb.org, accessed on 25 July 2021). The third wave was supported by Jacobs Foundation, Switzerland. The views expressed here are those of the authors. They are not necessarily those of ISCWeB.

Conflicts of Interest: The authors declare no conflict of interest. 


\section{References}

1. Thomas, P.; Jones, L.; Efroymson, D. Cities for Children: Defining the Dream and Achieving the Reality; HealthBridge Foundation of Canada: Ottawa, ON, Canada, 2012. Available online: https://healthbridge.ca/images/uploads/library/Cities_for_Children_ India_final.pdf (accessed on 3 April 2021).

2. United Nations. Transforming Our World: The 2030 Agenda for Sustainable Development; United Nations: New York, NY, USA, 2015. Available online: https:// sustainabledevelopment.un.org/content/documents/21252030\%20Agenda\%20for\%20Sustainable\% 20Development\%20web.pdf (accessed on 21 June 2021).

3. United Nations. Global Indicator Framework for the Sustainable Development Goals and Targets of the 2030 Agenda for Sustainable Development; United Nations: New York, NY, USA, 2018. Available online: https://unstats.un.org/sdgs/indicators/Global\%20 Indicator\%20Framework\%20after\%20refinement_Eng.pdf (accessed on 21 June 2021).

4. World Health Organization. Keeping the Vector Out: Housing Improvements for Vector Control and Sustainable Development; World Health Organization: Geneva, Switzerland, 2017. Available online: https://www.who.int/publications/i/item/9789241513166 (accessed on 15 March 2021).

5. United Nations. The 2030 Agenda and the Sustainable Development Goals: An opportunity for Latin America and the Caribbean; (LC/G.2681-P/Rev.3); United Nations: Santiago, Chile, 2018. Available online: https://repositorio.cepal.org/bitstream/handle/ 11362/40156/S1801140_en.pdf (accessed on 21 June 2021).

6. Morton, S.; Pencheon, D.; Squires, N. Sustainable Development Goals (SDGs), and their implementation: A national global framework for health, development and equity needs a systems approach at every level. Br. Med. Bull. 2017, 124, 81-90. [CrossRef]

7. Okulicz-Kozaryn, A.; Valente, R.R. Livability and Subjective Well-Being Across European Cities. Appl. Res. Qual. Life 2019, 14, 197-220. [CrossRef]

8. Bălțătescu, S. Ruut Veenhoven's Livability Concept and Children's Happiness Around the Globe. In The Pope of Happiness, Social Indicators Research Series; Michalos, A.C., Ed.; Springer: Cham, Switzerland, 2021; Volume 82, pp. 1-13. [CrossRef]

9. Veenhoven, R. Livability theory. In Encyclopedia of Quality of Life and Well-Being Research; Michalos, A.C., Ed.; Springer: Dordrecht, The Netherlands, 2014; pp. 3645-3647. [CrossRef]

10. Leby, J.L.; Hashim, A.H. Liveability Dimensions and Attributes: Their Relative Importance in the Eyes of Neighborhood Residents. J. Constr. Dev. Ctries. 2010, 15, 67-91.

11. Burton, M. Quality of place. In Encyclopedia of Quality of Life and Well-Being Research; Michalos, A.C., Ed.; Springer: Dordrecht, The Netherlands, 2014; pp. 5312-5314. [CrossRef]

12. Veenhoven, R. The Four Qualities of Life Ordering Concepts and Measures of the Good Life. In The Exploration of Happiness, Happiness Studies Book Series; Delle Fave, A., Ed.; Springer: Dordrecht, The Netherlands, 2013; pp. 1-39. [CrossRef]

13. United Nations. Indicators of Sustainable Development: Guidelines and Methodologies; Economic \& Social Affairs: New York, NY, USA, 2007. Available online: https://sustainabledevelopment.un.org/content/documents/guidelines.pdf (accessed on 15 March 2021).

14. Reinert, K.A. No small hope: The basic goods imperative. Rev. Soc. Econ. 2011, 69, 55-76. [CrossRef]

15. Rao, N.D.; Min, J. Decent Living Standards: Material Prerequisites for Human Wellbeing. Soc. Indic. Res. 2018, 138, 1-20. [CrossRef]

16. Krishnan, V. Development of a Multidimensional Living Conditions Index (LCI). Soc. Indic. Res. 2015, 120, 455-481. [CrossRef]

17. Jensen, J.; Spittal, M.; Crichton, S.; Sathiyandra, S.G.; Krishnan, V. Direct Measurement of Living Standards: The New Zealand ELSI Scale; Ministry of Social Development: Wellington, New Zealand, 2002.

18. United Nations. The Convention on the Rights of the Child; United Nations: New York, NY, USA, 1990. Available online: https://www.ohchr.org/documents/professionalinterest/crc.pdf (accessed on 8 May 2021).

19. UNICEF. Child Poverty in Perspective: An Overview of Child Well-Being in Rich Countries. A Comprehensive Assessment of the Lives and Well-Being of Children and Adolescents in the Economically Advanced Nations. Report Card 7; UNICEF Innocenti Research Centre: Florence, Italy, 2007. Available online: https: / / www.unicef-irc.org/publications/445-child-poverty-in-perspective-an-overviewof-child-well-being-in-rich-countries.html (accessed on 7 May 2021).

20. European Commission. Child Poverty and Well-Being in the EU. Current Status and Way Forward; Office for the Official Publications of the European Communities: Luxembourg, 2008.

21. OECD. Doing Better for Children; OECD: Paris, France, 2009.

22. Winston, N.; Pareja Eastaway, M. Sustainable Housing in the Urban Context: International Sustainable Development Indicator Sets and Housing. Soc. Indic. Res. 2008, 87, 211-221. [CrossRef]

23. Clair, A. Housing: An Under-Explored Influence on Children's Well-Being and Becoming. Child Indic. Res. 2019, 12, 609-626. [CrossRef]

24. Smith, S.J.; Cigdem, M.; Ong, R.; Wood, G. Wellbeing at the edges of ownership. Environ. Plan. A 2017, 49, 1080-1098. [CrossRef]

25. Vandivere, S.; Hair, E.C.; Theokas, C.; Cleveland, K.; McNamara, M.; Atienza, A.; Vandivere, S. How Housing Affects Child Wellbeing; Funders' Network for Smart Growth and Livable Communities: Washington, DC, USA, 2006. Available online: http:/ / citeseerx.ist.psu.edu/viewdoc/download?doi=10.1.1.526.4638\&rep=rep1\&type=pdf (accessed on 8 May 2021). 
26. Rees, G.; Bradshaw, J. Children's Worlds National Report: England; SPRU Social Policy Research Unit and University of York: Heslington, York, UK, 2020. Available online: https://isciweb.org/wp-content/uploads/2020/08/England-National-ReportWave-3.pdf (accessed on 12 June 2021).

27. Chaplin, L.N.; Lowrey, T.M.; Ruvio, A.A.; Shrum, L.J.; Vohs, K.D. Age differences in children's happiness from material goods and experiences: The role of memory and theory of mind. Int. J. Res. Mark. 2020, 37, 572-586. [CrossRef]

28. Solari, C.D.; Mare, R.D. Housing crowding effects on children's wellbeing. Soc. Sci. Res. 2012, 41, 464-476. [CrossRef] [PubMed]

29. Ruonavaara, H. Theory of Housing, From Housing, About Housing, Housing. Theory Soc. 2018, 35, 178-192. [CrossRef]

30. Streimikiene, D. Quality of Life and Housing. Int. J. Inf. Educ. Technol. 2015, 5, 140-145. [CrossRef]

31. Clark, H.; Coll-Seck, A.M.; Banerjee, A.; Peterson, S.; Dalglish, S.L.; Ameratunga, S.; Balabanova, D.; Bhan, M.K.; Bhutta, Z.A.; Borrazzo, J.; et al. A future for the world's children? A WHO-UNICEF- Lancet Commission. Lancet 2020, 395, 605-658. [CrossRef]

32. Dedman, D.J.; Gunnell, D.; Smith, G.D.; Frankel, S. Childhood housing conditions and later mortality in the Boyd Orr cohort. J. Epidemiol. Community Health 2001, 55, 10-15. [CrossRef] [PubMed]

33. Rybkowska, A.; Schneider, M. Housing Conditions in Europe in 2009; Eurostat. Statistics in focus, 4/2011, Population and social conditions; 2011. Available online: https:/ / ec.europa.eu/eurostat/documents/3433488/5578396/KS-SF-11-004-EN.PDF/2ef3 ac6a-9d13-4911-8808-20145b2a125a (accessed on 16 May 2021).

34. Herbers, D.J.; Mulder, C.H. Housing and subjective well-being of older adults in Europe. J. Hous. Built Environ. 2017, 32, 533-558. [CrossRef]

35. Marguerit, D.; Cohen, G.; Exton, C. Child Well-Being and the Sustainable Development Goals: How Far Are OECD Countries from Reaching the Targets for Children and Young People? OECD Statistics Working Papers, No. 2018/05; OECD Publishing: Paris, France, 2018.

36. Dockery, M.; Kendall, G.; Li, J.; Mahendran, A.; Ong, R.; Strazdins, L. Housing and Children's Development and Wellbeing: A Scoping Study, AHURI Final Report No. 149; Australian Housing and Urban Research Institute Limited: Melbourne, Australia, 2010. Available online: https:/ / www.ahuri.edu.au/research/final-reports/149 (accessed on 1 April 2021).

37. O'Sullivan, K.C.; Howden-Chapman, P.; Sim, D.; Stanley, J.; Rowan, R.L.; Harris Clark, I.K.; Morrison, L.A. Waiopehu College 2015 Research Team. Cool? Young people investigate living in cold housing and fuel poverty. A mixed methods action research study. SSM Popul. Health 2017, 3, 66-74. [CrossRef]

38. Office for National Statistics UK. Children's Views on Well-Being and What Makes a Happy Life, UK: 2020. A Qualitative Analysis of Children's Perspectives on Their Well-Being and What Makes A Happy Life for a Child Using UK Wide Focus Groups; Office for National Statistics UK: London, UK, 2020. Available online: https://www.ons.gov.uk/peoplepopulationandcommunity/wellbeing/ articles/childrensviewsonwellbeingandwhatmakesahappylifeuk2020/2020-10-02 (accessed on 15 May 2021).

39. Barnes, M.; Butt, S.; Tomaszewski, W. The Dynamics of Bad Housing: The Impact of Bad Housing on the Living Standards of Children; National Centre for Social Research; Shelter: London, UK, 2008.

40. Rees, G.; Tonon, G.; Mikkelsen, C.; de la Vega, R.L. Urban-rural variations in children's lives and subjective well-being: A comparative analysis of four countries. Child. Youth Serv. Rev. 2017, 80, 41-51. [CrossRef]

41. Lien, H.M.; Wu, W.C.; Lin, C.C. New evidence on the link between housing environment and children's educational attainments. J. Urban Econ. 2008, 64, 408-421. [CrossRef]

42. Rees, G.; Bradshaw, J. Exploring low subjective well-being among children aged 11 in the UK: An analysis using data reported by parents and by children. Child Indic. Res. 2017, 11, 27-56. [CrossRef]

43. Lazăr, A.R.; Hatos, A. Religiosity and Generosity of Youth. The Results of a Survey with 8th Grade Students from Bihor County (Romania). Rom. J. Multidimens. Educ. 2019, 11, 93-118. [CrossRef]

44. Coley, R.L.; Leventhal, T.; Lynch, A.D.; Kull, M. Relations between housing characteristics and the well-being of low-income children and adolescents. Dev. Psychol. 2013, 49, 1775-1789. [CrossRef]

45. Mohan, G. Young, poor, and sick: The public health threat of energy poverty for children in Ireland. Energy Res. Soc. Sci. 2021, 71, 101822. [CrossRef]

46. Harker, L. Chance of a Lifetime. The Impact of Bad Housing on Children's Lives; Shelter: London, UK, 2006.

47. Ngorosho, D. Key Indicators of Home Environment for Educational Research in Rural Communities in Tanzania. Child Indic. Res. 2010, 3, 327-348. [CrossRef]

48. Burgess, S.R.; Hecht, S.A.; Lonigan, C.J. Relations of the home literacy environment (HLE) to the development of reading-related abilities: A one-year longitudinal study. Read. Res. Q. 2002, 37, 408-426. [CrossRef]

49. Biedinger, N. The influence of education and home environment on the cognitive outcomes of preschool children in Germany. Child Dev. Res. 2011, 2011, 916303. [CrossRef]

50. Lehrl, S.; Evangelou, M.; Sammons, P. The home learning environment and its role in shaping children's educational development. Sch. Eff. Sch. Improv. 2020, 31, 1-6. [CrossRef]

51. Melhuish, E.C.; Phan, M.B.; Sylva, K.; Sammons, P.; Siraj-Blatchford, I.; Taggart, B. Effects of the Home Learning Environment and Preschool Center Experience upon Literacy and Numeracy Development in Early Primary School. J. Soc. Issues 2008, 64, 95-114. [CrossRef]

52. Niklas, F.; Cohrssen, C.; Lehrl, S.; Napoli, A.R. Editorial: Children's Competencies Development in the Home Learning Environment. Front. Psychol. 2021, 12, 706360. [CrossRef] 
53. Caldwell, B.M.; Bradley, R.H. Home Observation for Measurement of the Environment; University of Arkansas: Little Rock, AR, USA, 1984

54. Bradley, R.H. Constructing and Adapting Causal and Formative Measures of Family Settings: The HOME Inventory as Illustration. J. Fam. Theory Rev. 2015, 7, 381-414. [CrossRef]

55. Bradley, R.H.; Caldwell, B.M.; Rock, S.L.; Hamrick, H.M.; Harris, P. Home Observation for Measurement of the Environment: Development of a Home Inventory for Use with Families Having Children 6 to 10 Years Old. Contemp. Educ. Psychol. 1988, 13, 58-71. [CrossRef]

56. Smith, E. Using Secondary Data in Educational and Social Research; McGraw-Hill Education: New York, NY, USA, 2008.

57. World Bank. Country and Lending Groups. Country Classification by Region, by Income and by Lending; World Bank: Washington, DC, USA, 2021. Available online: https:/ / datahelpdesk.worldbank.org/knowledgebase/articles/906519 (accessed on 21 June 2021).

58. Rees, G.; Savahl, S.; Lee, B.J.; Casas, F. (Eds.) Children's Views on Their Lives and Well-Being in 35 Countries: A Report on the Children's Worlds Project, 2016-19; Children's Worlds Project (ISCWeB): Jerusalem, Israel, 2020. Available online: https: // isciweb.org/wp-content/uploads/2020/08/Childrens-Worlds-Comparative-Report-2020.pdf (accessed on 20 May 2021). 